\title{
ECOLOGY OF WEST NILE VIRUS TRANSMISSION AND ITS IMPACT ON BIRDS IN THE WESTERN HEMISPHERE
}

\author{
Author(s): A. Marm Kilpatrick, Shannon L. LaDeau, Peter P. Marra \\ Source: The Auk, 124(4):1121-1136. \\ Published By: The American Ornithologists' Union \\ https://doi.org/10.1642/0004-8038(2007)124[1121:EOWNVT]2.0.CO;2 \\ URL: http://www.bioone.org/doi/ \\ full/10.1642/0004-8038\%282007\%29124\%5B1121\%3AEOWNVT\%5D2.0.CO\%3B2
}

BioOne (www.bioone.org) is a nonprofit, online aggregation of core research in the biological, ecological, and environmental sciences. BioOne provides a sustainable online platform for over 170 journals and books published by nonprofit societies, associations, museums, institutions, and presses.

Your use of this PDF, the BioOne Web site, and all posted and associated content indicates your acceptance of BioOne's Terms of Use, available at www.bioone.org/page/terms_of_use.

Usage of BioOne content is strictly limited to personal, educational, and non-commercial use.

Commercial inquiries or rights and permissions requests should be directed to the individual publisher as copyright holder. 


\title{
The Auk
}

A Quarterly

Journal of Ornithology

Vol. 124 No. 4 October 2007

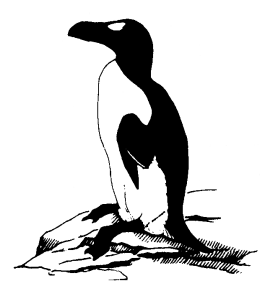

The Auk 124(4):1121-1136, 2007

(c) The American Ornithologists' Union, 2007.

Printed in USA.

\section{PERSPECTIVES IN ORNITHOLOGY}

\section{ECOLOGY OF WEST NILE VIRUS TRANSMISSION AND ITS IMPACT ON BIRDS IN THE WESTERN HEMISPHERE}

\author{
A. Marm Kilpatrick, ${ }^{1,3}$ Shannon L. LaDeau, ${ }^{2}$ and Peter P. Marra ${ }^{2}$ \\ ${ }^{1}$ Consortium for Conservation Medicine, 460 West 34th Street, 17th floor, New York, New York 10001, USA; and \\ ${ }^{2}$ Smithsonian Migratory Bird Center, National Zoological Park, P.O. Box 37012, MRC 5508, \\ Washington, D.C. 20013, USA
}

West Nile virus (WNV) was introduced into the western hemisphere in 1999 near New York City, where it caused substantial mortality in corvids and a small number of human cases (Nash et al. 2001). Genetic analysis showed that the introduced virus was most similar to a genotype isolated in Israel in 1998 (Lanciotti et al. 1999), and more virulent for some bird species (but not for others) than genotypes from Kenya and Australia (Kunjin virus) (Brault et al. 2004, 2007; Langevin et al. 2005). The virus is a plussense single-stranded RNA virus in the family Flaviviridae, which also includes Japanese encephalitis, St. Louis encephalitis, yellow fever, and dengue fever viruses (Hayes 1989).

From 1999 to 2006, WNV caused 26,274 reported human cases in the United States and Canada, including 9,942 cases of encephalitis, and 1,008 deaths (Centers for Disease Control and Prevention [CDC] 2007, Health Canada 2007). The actual number of infections, based on serosurveys, is estimated to be more than 1.4 million, with 280,000 illnesses (Petersen and Hayes 2004, CDC 2007). West Nile virus has also caused widespread disease in horses in North America (with $~ 40 \%$ of cases being fatal) and tens of thousands of deaths before

${ }^{3}$ E-mail: kilpatrick@conservationmedicine.org the advent of vaccination (Hall and Khromykh 2004). Several human vaccines are being developed, but so far none have been approved for use by the Federal Drug Administration (FDA) (Kramer et al. 2007). In contrast to the situation in North America, few human or horse illnesses have been observed in the tropics. The reasons for the absence of WNV in the tropics are unknown, but several hypothetical explanations have been put forth, including the idea that protective immunity has been conferred from other circulating flaviviruses, differences in the avian-host and mosquito-vector communities, and differences in the virulence of the virus when it circulates in the tropics (Tesh et al. 2002, Weaver and Barrett 2004, Fang and Reisen 2006, Komar and Clark 2006).

Substantial research has been done on many aspects of WNV virology, ecology, and public health since its introduction in 1999. There have been several recent reviews of the ecology of WNV transmission (Komar 2003, Marra et al. 2004, Weaver and Barrett 2004, Hayes et al. 2005), and a large body of literature is available on a closely related virus, the St. Louis encephalitis virus (Monath 1980). However, since the most recent reviews were published, substantial work has been done that greatly increases our understanding of the distribution and ecology of transmission of this virus and its effect on 
bird populations. The present review focuses on insights gained in these areas and highlights several areas of research that require immediate attention.

\section{SPREAD}

Distribution.-By 2004, just five years after its introduction, WNV had spread throughout much of the United States, including 47 of the 48 lower states, into 9 provinces in Canada, throughout Mexico, onto several islands in the Caribbean, and into several countries in Central and South America (Dupuis et al. 2003, 2005; Estrada-Franco et al. 2003; Cruz et al. 2005; Mattar et al. 2005; Farfan-Ale et al. 2006; Komar and Clark 2006; Morales et al. 2006; Bosch et al. 2007) (Fig. 1). Its apparent absence from countries in Central and South America is more likely attributable to a lack of effort to detect it than to the absence of the virus, because all these countries share migratory birds and other pathways (see below) with countries where it has been shown to be circulating (Fig. 1). In the United States, Canada, Mexico, and Argentina, the virus has been isolated from mosquitoes, birds, humans, or horses. However, within the tropical latitudes south of Mexico, no viral isolates have been obtained except for a recent (2007) isolate from Puerto Rico (L. D. Kramer pers. comm.). Evidence of local transmission has been based primarily on the presence of WNV-specific antibodies in resident birds or horses. Comparison of antibody titres using

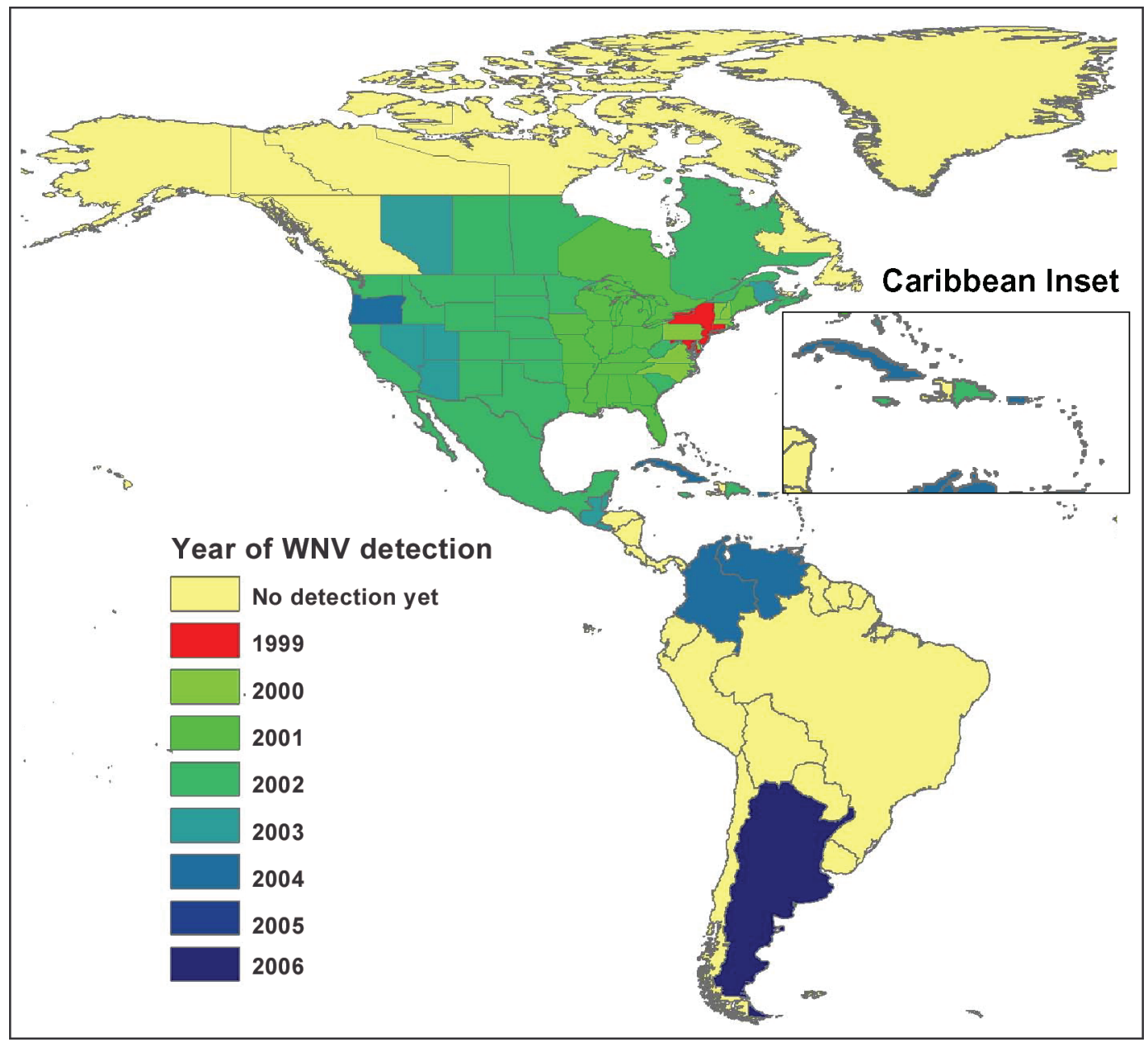

Fig. 1. Year of first detection of West Nile virus (WNV) in the Western Hemisphere. The virus may have been introduced months or even years earlier than when it was first detected. 
plaque-reduction neutralization assays has been used to exclude the possibility that WNVneutralizing antibodies resulted from exposure to other cross-reacting flaviviruses.

Pathways of spread. - The pathways by which WNV has and will spread are difficult to determine but likely include migrating birds, dispersal of nonmigratory birds, movement of mosquitoes by flight or wind, and human transport of mosquitoes, birds, or other animals (Rappole et al. 2000; Peterson et al. 2003; Kilpatrick et al. 2004, 2006b; Reisen et al. 2004). Efforts to determine the role of migrating birds in the spread of WNV have included laboratory infection studies with birds in migratory condition (Owen et al. 2006), efforts to isolate virus from birds during migratory periods ( $R$. McLean et al. unpubl. data), sampling of birds killed by communication towers and skyscrapers (P. Marra and A. DuPuis unpubl. data), and modeling efforts (Peterson et al. 2003). So far, none of these studies have provided conclusive evidence that migratory birds are transporting the virus long distances. Definitive evidence would require tracking a known viremic (virus in the blood) bird in the process of migration.

\section{ECOLOGY OF TRANSMisSion}

Transmission cycle.-West Nile virus is believed to be transmitted primarily between mosquitoes and birds in a bird-to-mosquitoto-bird cycle (see below for a discussion of the role of mammals). When mosquitoes feed on an infected or viremic bird, some fraction may become infected, depending on the magnitude of viremia and the susceptibility of the mosquito (Turell et al. 2002). After 1-14 days (depending on temperature; L. D. Kramer et al. unpubl. data), the virus may escape the midgut of the mosquito and infect the salivary glands, resulting in an infectious mosquito (Turell et al. 2002). Following a bite from this infectious mosquito, nearly all birds and mammals become infected, and most exhibit a viremic period of one to seven days (occasionally longer; Komar et al. 2003) that completes the cycle.

For birds that survive (death usually occurs between days 4 and 8 postinfection; Komar et al. 2003), antibodies begin to appear after day 4 (Styer et al. 2006). These antibodies are long-lasting and confer protection against re-infection with WNV (Fang and Reisen
2006). In addition, there appears to be some cross-protection against several flaviviruses, including WNV and St. Louis and Japanese encephalitis viruses (Tesh et al. 2002, Fang and Reisen 2006).

Other modes of transmission have been demonstrated, including direct bird-to-bird transmission (Komar et al. 2003), vertical transmission in mosquitoes (that may facilitate overwintering of the virus) (Nasci et al. 2001, Dohm et al. 2002b), and nearly instantaneous transmission between infected and uninfected mosquitoes simultaneously feeding on the same host. This last mode was originally believed to be nonviremic transmission (Higgs et al. 2005). Recent evidence suggests that infection of these cofeeding mosquitoes appears to be caused by a transient viremia from virus injected into the host by the infected mosquito, rather than by nonviremic transmission (Reisen et al. 2007b).

Vectors.-At least 62 species of mosquitoes have tested positive for WNV infection in North America (CDC 2007). However, finding a mosquito infected with WNV does not imply transmission or importance in transmission dynamics. Determining the importance of each species in local transmission requires quantitatively integrating mosquito abundance, prevalence of infection, vector competence, feeding behavior and, where possible, longevity (Reeves 1965, Kilpatrick et al. 2005). The results of such an analysis suggest that only a few (one to three) species at each site play important roles in enzootic (bird-to-bird) or epidemic (bird-to-human) transmission (Kilpatrick et al. 2005). The primary enzootic and epizootic vectors in northeast and north-central North America appear to be Culex pipiens and $C x$. restuans (Kilpatrick et al. 2005). These species are often relatively abundant, are moderately competent, frequently show the highest prevalence of infection, and feed in large part on birds but also, sometimes, on humans and other mammals (Bernard et al. 2001; Andreadis et al. 2004; Kilpatrick et al. 2005, 2006c, d). In some locations, $C x$. salinarius may also be an important epizootic or bridge vector (Andreadis et al. 2004), because it feeds frequently on both birds and mammals (Kilpatrick et al. 2005).

Quantitative analyses of vector importance are lacking for other regions, but species believed to be important on the basis of available data include $C x$. quinquefasciatus across southern 
North America and in Central and South America (Turell et al. 2005), Cx. nigripalpus and Cx. erraticus in southeastern parts of the United States (Blackmore et al. 2003, Cupp et al. 2007), and C. tarsalis across much of western North America (Reisen et al. 2004, Turell et al. 2005). Culex pipiens may also be important in urban areas in the western United States (Bolling et al. 2007). Other species of mosquitoes, including Aedes albopictus and $A e$. vexans, have been proposed as potential epizootic or bridge vectors (Turell et al. 2005), but the only quantitative analysis performed so far suggested that $A$ e. vexans and other non-Culex species were relatively unimportant in transmission to humans and other mammals (Kilpatrick et al. 2005) and would be even less important for bird-to-bird transmission.

Vectors other than mosquitoes have also been considered in the transmission of WNV. Laboratory transmission was demonstrated in soft ticks (Hutcheson et al. 2005) but did not occur in hard ixodid ticks (Reisen et al. 2007a). In general, ticks are not believed to play a major role in enzootic transmission but may act as a reservoir, because they can remain infected for long periods (Lawrie et al. 2004).

Hosts. - The importance of each vertebrate host in viral transmission depends on (1) hostreservoir competence, which is a function of the intensity and duration of viremia and survival of WNV-infected birds; and (2) contact rates between that host and competent mosquito vectors (Hammon et al. 1943, Scott 1988). Although $\geq 317$ species of birds and $\geq 30$ species of mammals have been found infected with WNV (Marra et al. 2004, CDC 2007), only a very small subset of these are likely to play important roles in WNV transmission. The only analysis, so far, to quantitatively integrate data on these two factors showed that a single relatively uncommon species, American Robin (Turdus migratorius), was responsible for $\sim 60 \%$ of $\mathrm{WNV}$-infectious mosquitoes across five residential and urban sites in the mid-Atlantic United States (Kilpatrick et al. 2006c).

Laboratory infection studies to estimate host competence have been published for 44 species of nondomesticated birds in 23 families and 11 orders (Komar et al. 2003, 2005; Reisen et al. 2005a, b, 2006, 2007a; Clark et al. 2006; Nemeth et al. 2006; Owen et al. 2006; Reisen and Hahn 2007; Platt et al. 2008), 3 species of wild mammals (Tiawsirisup et al. 2005b, Root et al. 2006,
Platt et al. 2007), and 5 species of reptiles and one amphibian (Klenk and Komar 2003, Klenk et al. 2004). In these experiments, animals are infected by either allowing infectious mosquitoes to feed on them or by an intramuscular or subcutaneous injection of virus. Blood samples are then taken approximately daily until animals die or clear the virus from their blood (usually one to seven days after infection). These data can then be used to estimate host competence or the fraction of vectors biting an infected host that is likely to become infectious.

Vertebrate host competence. - Host competence is a term that describes the infectiousness of an infected host. For WNV, it can be quantified for an individual as the sum (over the viremic period) of the daily probabilities that a mosquito biting that bird will become infectious for WNV (Komar et al. 2003). Thus, hosts that have long viremic periods and high-titred viremias (and, thus, high infectiousness to biting mosquitoes) are highly competent. The host-competence index for a species should estimate the average infectiousness of several individuals and weigh the infectiousness of each individual equally. Calculating a numerical value of host competence (e.g., the "competence index"; Komar et al. 2003) for a species requires an equation for the fraction of mosquitoes that will become infectious after feeding on a host as a function of host viremia. Although the viremiainfectiousness relationships appear to differ for different mosquito species, the lowest viremia that leads to any infectious-transmitting mosquitoes appears to be in the range of $10^{4}$ to $10^{5}$ plaque-forming units (PFU) $\mathrm{mL}^{-1}$ (Sardelis et al. 2001, Reisen et al. 2005a, Tiawsirisup et al. 2005a, Turell et al. 2005 and references therein). However, this threshold is of limited importance, and attention should be focused on the actual fraction of mosquitoes that become infectious, which starts at zero at $\sim 10^{4.6} \mathrm{PFU} \mathrm{mL} \mathrm{mL}^{-1}$ for $C x$. pipiens and increases linearly with the logarithm of host viremia (Tiawsirisup et al. 2005a).

We calculated a competence index for each of the 53 wild vertebrate species that have been studied by experimental infection. We used a viremia-infectiousness relationship for $C x$. pipiens that was based on data from three studies of mosquitoes held at $26-27^{\circ} \mathrm{C}$ after feeding (Turell et al. 2000, Dohm et al. 2002a, Tiawsirisup et al. 2005a): \% infectious (transmitting) $=0.1349 \times$ $\log 10$ (Viremia) $-0.6235\left(R^{2}=0.66, P=0.001, n=\right.$ 
13). This equation gives a higher infectiousness for a given viremia than that used previously (\% infectious [transmitting] $=0.1 \times \log 10$ [viremia] - 0.48; appendix D in Komar et al. 2003), but this previous equation was based on only two data points (Turell et al. 2000). We calculated competence indices for each species by first calculating an average daily infectiousness by averaging the infectiousness of individuals on that day (obtained by inserting each individual's logged, base 10, viremias into the equation). If an individual had a viremia less than the threshold of zero infectiousness $\left(10^{4.62} \mathrm{PFU} \mathrm{mL} \mathrm{mL}^{-1}\right)$, its infectiousness was set to zero before averaging across individuals. We then summed these species' average daily infectiousness values across the viremic period to give a competence index for the species. This analysis contrasts with a previous approach in which averaging was done on the raw (unlogged) viremia titres (Komar et al. 2003). Our averaging method produces an index for a species that weighs the infectiousness of each individual equally and avoids inflation of average viremia and infectiousness by a single animal with a high-titred viremia. Finally, we did not adjust competence indices depending on needle or mosquito inoculations as has been done previously (Komar et al. 2005), because recent work suggests that although viremias are higher for mosquito inoculation than needle injection during the first $24 \mathrm{~h}$ postinfection, they were lower on days 3-4 postinfection (Styer et al. 2006). We were unable to derive a single conversion between the two inoculation methods or to account for different inoculation doses on the basis of the available data. We encountered one further difficulty in estimating host competence from published data where only average daily viremias were reported, rather than daily viremia titres for each individual. If average daily viremia values included individuals with viremia titres both above and below the threshold of infection, infectiousness for the species on that day was underestimated.

Using this approach, the eight most competent hosts included species from five families and two orders of birds (Passeriformes: Corvidae: Blue Jay [Cyanocitta cristata], Western Scrub-Jay [Aphelocoma californica], American Crow [Corvus brachyrhynchos], and Black-billed Magpie [Pica hudsonia]; Icteridae: Common Grackle [Quiscalus quiscula]; Fringillidae: House Finch [Carpodacus mexicanus]; Passeridae: House
Sparrow [Passer domesticus]; Charadriiformes: Laridae: Ring-billed Gull [Larus delawarensis]) (Fig. 2). The next group of 11 moderately competent hosts included five passerines, three raptors, and Greater Sage-Grouse (Centrocercus urophasianus). The remaining 34 species that were weakly competent or incompetent included some passerines, doves, pheasants, ducks, and geese. Overall, these data suggest that significant variation in competence exists at all taxonomic levels, but variability is greater between families of birds than within them (Kilpatrick et al. 2006c), and a family average could be used as a surrogate for an unstudied species within that family. The data in Figure 2 can be used, in combination with mosquitofeeding data (see below), to determine the community average reservoir competence at a site and to test hypotheses such as the dilution effect. This theory attempts to link the prevalence of infection in vectors with the competence and diversity of the vertebrate host community (Ostfeld and Keesing 2000). These competence data clearly indicate that characterizing all passerines as competent and all nonpasserines as incompetent (Ezenwa et al. 2006) is incorrect and may lead to spurious conclusions.

Birds have generally been considered the most important amplification hosts for WNV, and bird-biting mosquitoes of the genus Culex are believed to be the most important enzootic vectors (Turell et al. 2002, 2005; Kilpatrick et al. 2005). This is because mammals, reptiles, and amphibians generally have significantly lower viremias than many species of birds, resulting in a very small fraction of biting mosquitoes becoming infectious from these nonavian hosts (Fig. 2). In addition, birds are fed on much more frequently than these classes of animals by mosquitoes of the genus Culex that are most frequently infected (Apperson et al. 2002, 2004; Kilpatrick et al. 2006c, d; Molaei et al. 2006; Savage et al. 2007). For example, eastern chipmunk (Tamias striatus), the most competent wild mammal studied to date (Platt et al. 2007), has not been identified from any of the $>2,300$ Culex bloodmeals identified in the studies just cited. Similarly, in terms of infectiousness, their competence index was a low 0.36 (Fig. 2). This means that, on average, over the four-day viremic period, only $9 \%$ of mosquitoes feeding on chipmunks would become infectious with WNV. This low competence value was supported 


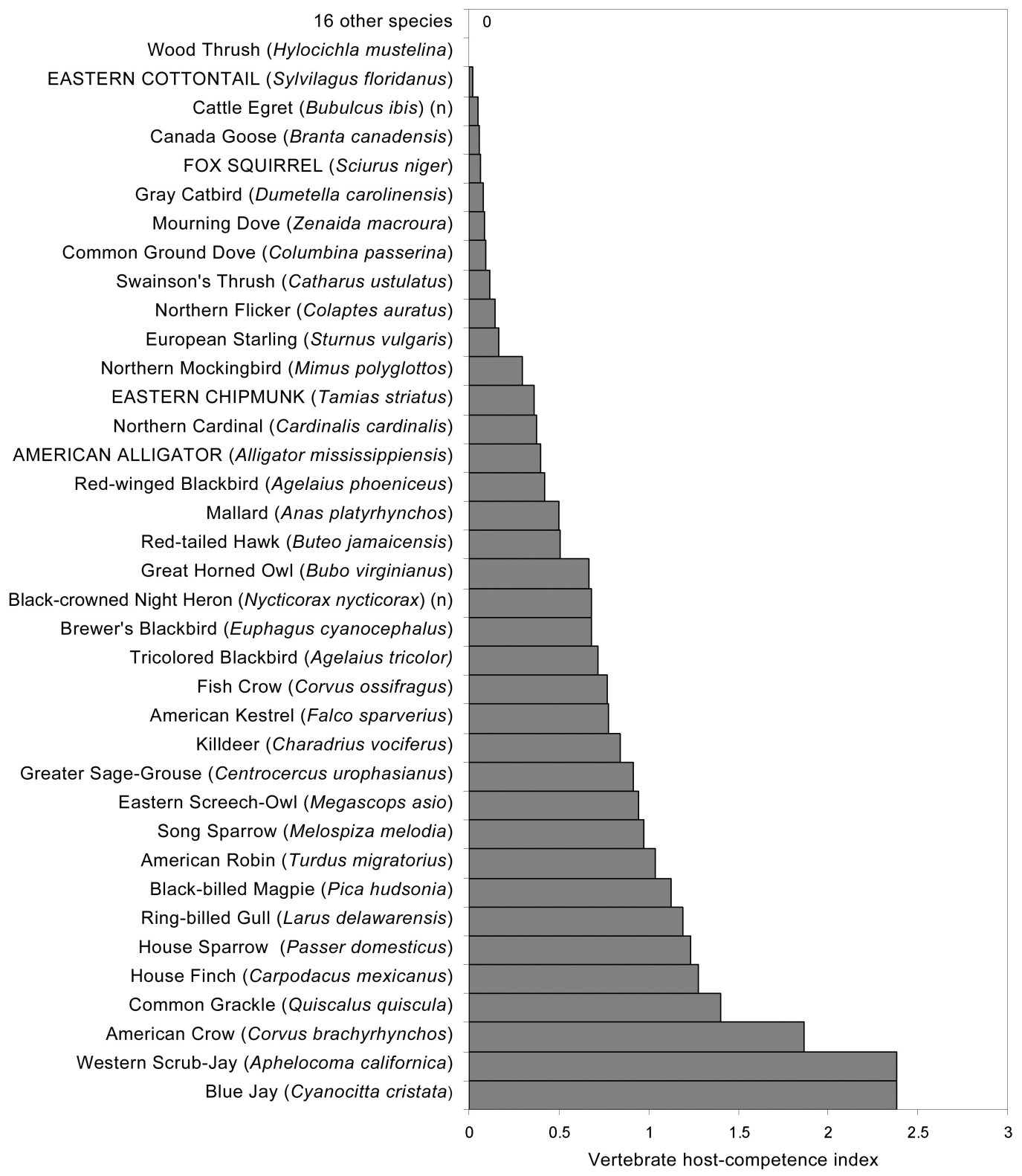

Fig. 2. West Nile virus host competence index values for birds, mammals, reptiles, and amphibians based on experimental infection studies. Each value represents the sum of the average daily probabilities of a host transmitting WNV to Culex pipiens. The "16 other species" with an index value of zero are Northern Bobwhite (Colinus virginianus), Japanese Quail (Coturnix japonica), Ring-necked Pheasant (Phasianus colchicus), American Coot (Fulica americana), Rock Pigeon (Columba livia), Monk Parakeet (Myiopsitta monachus), Budgerigar (Melopsittacus undulatus), California Quail (Callipepla californica), Brown-headed Cowbird (Molothrus ater), Barn Owl (Tyto alba), Gambel's Quail (C. gambelii), green iguana, (Iguana iguana), red-sided garter snake (Thamnophis sirtalis), red-ear slider (Trachymes scripta), and American bullfrog (Rana catesbeiana). Nonbirds are shown in all capital letters for clarity, and (n) refers to experimental infection of nestling birds. Viremias for rabbits were given in CID50 $\mathrm{mL}^{-1}$ and were converted to PFU mL ${ }^{-1}$ using the expression PFU mL ${ }^{-1}=-0.567306+0.987227 \mathrm{CID}^{-1} \mathrm{~mL}^{-1}$ (S. Tiawsirisup and K. B. Platt unpubl. data). 
by data from the same study, in which 2 of 84 Ae. triseriatus that fed on the viremic chipmunks became infectious and 1 of $9 C x$. pipiens became infected (but not infectious). Overall, mammals ranked 25th, 33rd, and 36th of the 53 species of birds, mammals, and reptiles studied (Fig. 2). It should be noted that although some mosquitoes can become infected from feeding on mammals and other vertebrate hosts with low viremias, very few become infectious (i.e., can transmit during a subsequent feeding).

Important areas for future research on host competence include determining (1) the difference in competence between nestling, hatchyear, and adult birds (Mahmood et al. 2004, Reisen et al. 2006, Griffing et al. 2007); (2) the competence of several families of birds that have not been studied (e.g., wrens [Troglodytidae], warblers [Parulidae], vireos [Vireonidae]); and (3) the role of host competence in WNV amplification.

Host-vector contact. - The second component that determines the role of a host in WNV amplification is contact rate with vectors. This is because a highly competent host will be important in pathogen amplification only if it is frequently fed on by mosquitoes. Several recent studies of mosquito feeding behavior have generated some general patterns. First, American Robins, a moderately competent host (Komar et al. 2003), appear to be fed on frequently by $C x$. pipiens across a broad area of the eastern United States including Tennessee (Savage et al. 2007), the mid-Atlantic (Kilpatrick et al. 2006c, d; Griffing et al. 2007), and the northeast (Apperson et al. 2002, 2004; Molaei et al. 2006). Second, feeding of $C x$. pipiens on American Robins decreases in the fall (Kilpatrick et al. 2006d, Molaei et al. 2006) at the same time that American Robins disperse from some urban and residential areas. This decrease in feeding has been associated with an increase in feeding on humans (Kilpatrick et al. 2006d). Recent work has shown that feeding of Cx. pipiens is influenced by genetic ancestry, but no change in genetic ancestry was detected over the mosquito season, which suggests that host availability is a more likely explanation for the feeding shift (Kilpatrick et al. 2007). Feeding also appears to shift from birds to mammals in other regions and for various species of mosquito, including $C x$. nigripalpus in Florida (Edman and Taylor 1968), Cx. tarsalis and Cx. pipiens in Colorado
(Tempelis et al. 1967), Cx. tarsalis in California (Tempelis et al. 1965), and Cx. erraticus in Alabama (Hassan et al. 2003), and this is likely to intensify WNV epidemics in humans in these regions (Kilpatrick et al. 2006d). Third, Mourning Doves (Zenaida macroura) appear to be fed on frequently in some areas (Kilpatrick et al. 2006c; Molaei et al. 2006, 2007) but, given their relatively low viremias (Komar et al. 2003, Reisen et al. 2005a), they are more likely to dampen than amplify WNV epidemics.

Key gaps in our knowledge include the feeding patterns at the species level of key WNV vectors $(C x$. tarsalis, $C x$. pipiens, $C x$. quinquefasciatus) in the Midwest, the western United States, Canada, and south of the United States. Although extensive work was done in the 1970s on mosquito feeding in the western United States (Tempelis 1974), the techniques available at that time did not allow easy identification of individual host species, and this precision is crucial for understanding WNV transmission (Kilpatrick et al. 2006c). Second, research on vector feeding should also include abundance surveys of the avian community at the time of collection of engorged mosquitoes, so feeding preferences (and consequences for amplification) can be determined (Hassan et al. 2003, Kilpatrick et al. 2006c). Third, additional studies that integrate mosquito feeding with host-competence data are needed to determine the key amplification and dampening hosts for WNV (Kilpatrick et al. 2006c) and help identify potential hotspots and potential control strategies, such as vaccination.

Avian seroprevalence studies. - Many studies have examined the seroprevalence of WNV antibodies in birds. Generalities emerging from this work include a higher seroprevalence (1) in adults than in young of the year (Beveroth et al. 2006, Gibbs et al. 2006, Reisen et al. 2006), (2) in residents than in migrants (Komar et al. 2005), and (3) in birds in urban and suburban than in birds from rural or forested habitats (Komar et al. 2005, Gibbs et al. 2006). Among common widespread species, the highest seroprevalence was observed in Northern Cardinals (Cardinalis cardinalis), followed by mimids (Mimidae: Northern Mockingbirds [Mimus polyglottos], Gray Catbirds [Dumetella carolinensis], and Brown Thrashers [Toxostoma rufum]), doves (Columbidae; Reisen et al. 2004, Ringia et al. 2004), thrushes (Turdidae: American Robins 
and Wood Thrushes [Hylocichla mustelina]), and House Sparrows (Komar et al. 2001, Beveroth et al. 2006). Seroprevalence studies offer some insight into relative patterns of exposure but are biased by fatal infections that occur in some species but not in others. Other key shortcomings of most seroprevalence studies include grouping of adult and hatch-year birds, despite the fact that birds of different ages have been exposed for different lengths of time. This makes it difficult to determine whether patterns of seroprevalence represent differences in age structure or exposure of birds. Similarly, most studies group all birds trapped over an entire transmission season, despite the fact that the probability of having WNV antibodies differs with capture date (Komar et al. 2005).

Spatial variation in transmission. - Surveillance by county health departments throughout the United States and Canada have shown that WNV transmission occurs in nearly all counties where efforts have been made to detect it (U.S. Geological Survey [USGS] 2007). However, the intensity of transmission, as measured by human incidence, varies by at least two orders of magnitude (CDC 2007). Mechanisms that are likely to create spatial variability in WNV transmission include mosquito abundance, host and vector competence, and vector-feeding behavior (Fonseca et al. 2004; Kilpatrick et al. 2005, 2006c, d, 2007; Cohen et al. 2007). Understanding the mechanistic drivers of spatial variation in transmission remains a major focus of current ecological research, as does the role of environmental factors (e.g., climate) in creating large populations of WNV mosquito vectors.

West Nile virus surveillance. - In the first few years after the introduction of $\mathrm{WNV}$, reporting and testing of dead birds proved to be the most sensitive indicator of the presence of WNV in an area and an indicator of earlyseason transmission (Guptill et al. 2003). In some areas, dead crow reporting (Eidson et al. 2001) and a spatial clustering model called DYCAST (Theophilides et al. 2003) have also been used to identify hot spots of transmission. Since then, however, public interest in reporting of dead birds has waned, and WNV budgets of health departments have been reduced significantly. As a result, new ways to estimate the risk of human epidemics and allocate resources for disease control are needed. Previous work has shown that temporal variation in human cases (Kilpatrick et al. 2006d) and spatial variation in nonhuman primate exposure to WNV (Cohen et al. 2007) were highly correlated with the abundance of WNVinfected human-feeding (or mammal-feeding) mosquitoes. This suggests that this risk measure (the sum across all mosquitoes of the product of mosquito abundance, prevalence, feeding frequency on humans, and modified vector competence; Kilpatrick et al. 2005) might be a useful index for allocating control efforts. It remains to be determined whether a single value (or temporal trend) can be used across sites for some of these measures (feeding frequencies, vector competence) and still maintain predictive utility of the risk index. Regardless, even collection of mosquito abundance and prevalence data is costly, and currently health departments are struggling to maintain budgets for these activities.

\section{Effects on Bird Populations}

The introduction of WNV in the Western Hemisphere was immediately accompanied by substantial mortality in corvids and several other bird species (Nash et al. 2001). A key question since that time has been what effect this disease would have on bird populations and other animals (Marra et al. 2004). Attention was also focused on those species that were already threatened or endangered, including Florida Scrub-Jays (Aphelocoma coerulescens), Whooping Cranes (Grus americana), California Condors (Gymnogyps californianus), Greater Sage-Grouse, and Kirtland's Warbler (Dendroica kirtlandii). The precipitous decline of some populations of Greater Sage-Grouse following WNV arrival provided an alarming demonstration of the possible effect of WNV on an already threatened species (Naugle et al. 2004). Thankfully, as of yet, no significant population effects of WNV have been observed in any other endangered or threatened species.

One approach that was taken with highly managed populations of Whooping Cranes and California Condors was to vaccinate captivereared birds with a DNA vaccine (Chang et al. 2007). The vaccinated animals developed protective antibodies, and vaccination may have prevented mortality, though the susceptibility of both species is unknown. This strategy of vaccinating threatened species or captive individuals offers temporary relief, but it interferes with the natural selection for resistance (Kilpatrick 2006) 
and, therefore, requires continuous management action.

After eight seasons of transmission, the impacts of WNV on populations of some species of birds are evident. Several early studies documented substantial effects of WNV on local populations of American Crows (Yaremych et al. 2004, Caffrey et al. 2005), Blue Jays (Komar et al. 2005), and Greater Sage-Grouse (Naugle et al. 2004). However, early attempts to determine the regional effects of WNV on bird populations (Bonter and Hochachka 2003, Caffrey 2003, Hochachka et al. 2004) failed to find uniform regional influences of WNV and instead found significant spatial heterogeneity in population trends.

In contrast, a recent broad-scale study across the United States found significant effects attributed to WNV on 7 of the 20 species studied (LaDeau et al. 2007). The declining species included corvids (American Crow and Blue Jay), thrushes (American Robin and Eastern Bluebird [Sialia sialis]), Tufted Titmouse (Baeolophus bicolor), Carolina Chickadee (Poecile carolinensis), Black-capped Chickadee [P. atricapillus), and House Wren (Troglodytes aedon). There was no clear evidence of WNV-related declines in 13 other species, but some were declining from other causes. A key result was that the species that were found to be affected by WNV were those that were predicted to suffer from WNV on the basis of a priori knowledge of mosquito-feeding patterns, serology, and susceptibility based on laboratory infections (LaDeau et al. 2007). In addition, the affected species were all common residents in urban and residential areas where WNV vectors are known to be present. This suggests that additional mosquito-feeding studies, when paired with serological investigations or experimental laboratory infection studies, may help pinpoint the other species that are likely to experience population effects. Large-scale monitoring efforts, such as the Breeding Bird Survey (BBS), can be used in conjunction with local telemetry or mark-recapture studies to confirm or refute these predictions and to identify species that may require immediate management attention. Unfortunately, many groups of birds (e.g., shorebirds, waterfowl, raptors) and certain habitats (e.g., urban areas, areas far from roads) remain poorly covered by current monitoring efforts. In addition, certain species may be too rare to be detected in mosquito-feeding studies. As a result, new, innovative techniques are needed to determine the effects of WNV and other emerging infectious diseases on wildlife.

The difference between the study that found widescale effects of WNV (LaDeau et al. 2007) and those done earlier (Bonter and Hochachka 2003, Caffrey 2003, Hochachka et al. 2004) may be the fact that LaDeau et al. (2007) used summer BBS data, rather than winter Christmas bird counts (CBC) and feeder watch counts. Winter count data may be less accurate for determining the local effects of $\mathrm{WNV}$, because the location where birds were counted is not necessarily the same as where populations were exposed to WNV during the summer. In addition, the greater effects observed by LaDeau et al. (2007) may be because several additional years of transmission had occurred between their analyses and previous studies. In support of this assertion, the population effects observed by LaDeau et al. (2007) were greater in areas of the eastern United States, where WNV had been present for longer than in the western United States. This begs the question of whether there are additional species of birds suffering significant effects from WNV (especially in western North America) and whether observed declines will continue to occur or will species recover or reach stable populations, but at lower levels.

A number of key questions remain regarding the influence of WNV on wildlife populations. First, what makes a species susceptible to morbidity or mortality from WNV infection? Available data show that there is a clear taxonomic component to susceptibility to WNV mortality, with corvids being almost universally susceptible, whereas doves tolerate infection quite well (Komar et al. 2003; Reisen et al. 2005a, 2006). However, this observation merely pushes the question back a step: What makes corvids and some other species more susceptible? Do they have poorer immune function or, more likely, are there virus-host interactions that result in high susceptibility to WNV? Similarly, why are some individuals of each species more susceptible to morbidity and mortality than others? Finally, why do mosquitoes prefer to feed on some species and individuals (Griffing et al. 2007) rather than others? Is feeding based on odor, roosting height or location, gregariousness, defensive 
behavior, or amount of exposed skin of a species or individual? Careful laboratory and field experiments will be required to address all these issues.

\section{Future Research Needs}

In addition to those questions already highlighted, several large areas of research remain unexplored. Foremost for the ecological community are the secondary effects of WNVcaused population declines. Many of the species that have been shown to be affected by WNV are also known to be important species in ecological processes including scavenging of carcasses, nest predation, seed dispersal, and control of insect pests (LaDeau et al. 2007). Substantially lower abundances of corvids may be accompanied by decreased nest predation, whereas lower abundances of American Robins and Eastern Bluebirds may decrease the dispersal of seeds. At present, no studies have investigated the potential secondary effects of WNV-induced population declines.

One key issue that challenges our ability to understand the ecology of WNV and predict its effects on wildlife and human health is the evolution of the virus itself, its vectors, and its hosts, all of which are likely occurring. For example, the introduced genotype of WNV (NY99) was displaced by a new genotype that was initially detected in 2001 (WN02), and this new genotype subsequently spread throughout North America (Davis et al. 2005). The displacement of the introduced genotype NY99 by WN02 is only beginning to be understood, but early studies have shown that it is more efficient at replicating in mosquitoes (Ebel et al. 2004, Moudy et al. 2007, L. D. Kramer et al. unpubl. data). Unfortunately, selection for increased virulence in birds may not be balanced by a reduction in the infectious period. This is because in most species, death usually occurs on days 4-8 (Komar et al. 2003, Fang and Reisen 2006) - at the same time that survivors clear the virus from the blood stream. As a result, increases in virulence are likely to result in higher host viremias (making hosts more infectious) and increased mortality, which would reduce the number of immune hosts remaining after infection. In short, it appears that the virus could be substantially more virulent before it would face any trade-offs between virulence and the length of the infectious period, in all but a few host species.

Taken together, all this highlights the importance of continued research on the virus, its vectors, and its vertebrate hosts throughout the Western Hemisphere. Substantial work needs to be done in developing countries to the south of the United States on the ecology of WNV transmission, as well as on the acquisition of more accurate measurements of population effects on wildlife. West Nile virus is just one in a series of avian diseases to emerge in recent years (Kilpatrick et al. 2006a). An integrated Western Hemisphere plan to cope with these biological invasions and strategies to minimize the risk of disease spread are urgently needed.

\section{Acknowledgments}

We thank N. Komar, W. Reisen, K. Platt, and N. Nemeth for providing raw viremia data, and W. Reisen and N. Komar for extensive comments that improved the paper. This work was funded by the National Institute of Allergy and Infectious Diseases (NIAID) contract \#NO1AI-25490, National Science Foundation (NSF) grant EF-0622391, as part of the joint Ecology of Infectious Disease program of the NSF and the National Institutes of Health, and by an NSF fellowship.

\section{Literature Cited}

Andreadis, T. G., J. F. Anderson, C. R. Vossbrinck, AND A. J. Main. 2004. Epidemiology of West Nile virus in Connecticut: A five-year analysis of mosquito data 1999-2003. Vector-Borne and Zoonotic Diseases 4:360-378.

Apperson, C. S., B. A. Harrison, T. R. UnNasch, H. K. Hassan, W. S. Irby, H. M. Savage, S. E. Aspen, D. W. Watson, L. M. Rueda, B. R. Engber, and R. S. Nasci. 2002. Hostfeeding habits of Culex and other mosquitoes (Diptera: Culicidae) in the Borough of Queens in New York City, with characters and techniques for identification of Culex mosquitoes. Journal of Medical Entomology 39:777-785.

Apperson, C. S., H. K. Hassan, B. A. Harrison, H. M. Savage, S. E. Aspen, A. Farajollahi, W. Crans, T. J. Daniels, R. C. Falco, M. Benedict, AND OTHERs. 2004. Host feeding patterns of established and potential 
mosquito vectors of West Nile virus in the eastern United States. Vector-Borne and Zoonotic Diseases 4:71-82.

Bernard, K. A., J. G. Maffei, S. A. Jones, E. B. Kauffman, G. D. Ebel, A. P. Dupuis II, K. A. Ngo, D. C. Nicholas, D. M. Young, P. Y. Shi, AND OTHERs. 2001. West Nile virus infection in birds and mosquitoes, New York State, 2000. Emerging Infectious Diseases 7:679-685.

Beveroth, T. A., M. P. WARd, R. L. Lampman, A. M. Ringia, And R. J. Novak. 2006. Changes in seroprevalence of West Nile virus across Illinois in free-ranging birds from 2001 through 2004. American Journal of Tropical Medicine and Hygiene 74:174-179.

Blackmore, C. G. M., L. M. Stark, W. C. Jeter, R. L. Oliveri, R. G. Brooks, L. A. Conti, and S. T. Wiersma. 2003. Surveillance results from the first West Nile virus transmission season in Florida, 2001. American Journal of Tropical Medicine and Hygiene 69:141-150.

Bolling, B. G., C. G. Moore, S. L. Anderson, C. D. Blair, and B. J. Beaty. 2007. Entomological studies along the Colorado front range during a period of intense West Nile virus activity. Journal of the American Mosquito Control Association 23:37-46.

Bonter, D. N, and W. M. НochachKa. 2003. Combined data of Project FeederWatch and the Christmas Bird Count indicate declines of chickadees and corvids: Possible impacts of West Nile virus. American Birds: The 103rd Christmas Bird Count:22-25.

Bosch, I., F. Herrera, J.-C. Navarro, M. Lentino, A. Dupuis, J. Maffei, M. Jones, E. Fernandez, N. Pérez, J. Pérez-Eman, and others. 2007. West Nile virus, Venezuela. Emerging Infectious Diseases 13:651-653.

Brault, A. C., C. Y.-H. Huang, S. A. Langevin, R. M. Kinney, R. A. Bowen, W. N. Ramey, N. A. Panella, E. C. Holmes, A. M. Powers, AND B. R. Miller. 2007. A single positively selected West Nile viral mutation confers increased virogenesis in American Crows. Nature Genetics 39:1162-1166.

Brault, A. C., S. A. Langevin, R. A. Bowen, N. A. Panella, B. J. Biggerstaff, B. R. Miller, and N. Komar. 2004. Differential virulence of West Nile strains for American Crows. Emerging Infectious Diseases 10:2161-2168.

Caffrey, C. 2003. Determining impacts of West Nile virus on crows and other birds.
American Birds: The 103rd Christmas Bird Count:12-13.

Caffrey, C., S. C. R. Smith, and T. J. Weston. 2005. West Nile virus devastates an American Crow population. Condor 107:128-132.

Centers for Disease Control and Prevention. 2007. West Nile virus. [Online.] Centers for Disease Control and Prevention, Atlanta, Georgia. Available at www.cdc.gov/ncidod/ dvbid/westnile/index.htm.

Chang, G.-J. J., B. S. Davis, C. Stringfield, and C. Lutz. 2007. Prospective immunization of the endangered California Condors (Gymnogyps californianus) protects this species from lethal West Nile virus infection. Vaccine 25:2325-2330.

Clark, L., J. Hall, R. McLean, M. Dunbar, K. Klenk, R. Bowen, and C. A. Smeraski. 2006. Susceptibility of Greater Sage-Grouse to experimental infection with West Nile virus. Journal of Wildlife Diseases 42:14-22.

Cohen, J. K., A. M. Kilpatrick, F. C. Stroud, K. Paul, F. Wolf, and J. G. Else. 2007. Seroprevalence of West Nile virus in nonhuman primates as related to mosquito abundance at two national primate research centers. Comparative Medicine 57:115-119.

Cruz, L., V. M. Cardenas, M. Abarca, T. Rodriguez, R. F. Reyna, M. V. Serpas, R. E. Fontaine, D. W. C. Beasley, A. P. A. T. Da Rosa, S. C. WeAVER, AND OTHERs. 2005. Short report: Serological evidence of West Nile virus activity in El Salvador. American Journal of Tropical Medicine and Hygiene 72:612-615.

Cupp, E. W., H. K. Hassan, X. Yue, W. K. Oldland, B. M. Lilley, and T. R. UnNasch. 2007. West Nile virus infection in mosquitoes in the Mid-South USA, 2002-2005. Journal of Medical Entomology 44:117-125.

Davis, C. T., G. D. Ebel, R. S. Lanciotti, A. C. Brault, H. Guzman, M. Siirin, A. Lambert, R. E. Parsons, D. W. C. Beasley, R. J. Novak, AND Others. 2005. Phylogenetic analysis of North American West Nile virus isolates, 2001-2004: Evidence for the emergence of a dominant genotype. Virology 342:252-265.

Dohm, D. J., M. L. O'Guinn, and M. J. Turell. 2002a. Effect of environmental temperature on the ability of Culex pipiens (Diptera: Culicidae) to transmit West Nile virus. Journal of Medical Entomology 39:221-225.

Dohm, D. J., M. R. Sardelis, and M. J. Turell. 2002b. Experimental vertical transmission 
of West Nile virus by Culex pipiens (Diptera: Culicidae). Journal of Medical Entomology 39:640-644.

Dupuis, A. P., II, P. P. Marra, and L. D. Kramer. 2003. Serologic evidence of West Nile virus transmission, Jamaica, West Indies. Emerging Infectious Diseases 9:860-863.

Dupuis, A. P., II, P. P. Marra, R. Reitsma, M. J. Jones, K. L. Louie, and L. D. Kramer. 2005. Short report: Serologic evidence for West Nile virus transmission in Puerto Rico and Cuba. American Journal of Tropical Medicine and Hygiene 73:474-476.

Ebel, G. D., J. Carricaburu, D. Young, K. A. Bernard, and L. D. Kramer. 2004. Genetic and phenotypic variation of West Nile virus in New York, 2000-2003. American Journal of Tropical Medicine and Hygiene 71:493-500.

Edman, J. D., AND D. J. TAYlor. 1968. Culex nigripalpus: Seasonal shift in the bird-mammal feeding ratio in a mosquito vector of human encephalitis. Science 161:67-68.

Eidson, M., L. [D.] Kramer, W. Stone, Y. Hagiwara, and K. Sсhмit. 2001. Dead bird surveillance as an early warning system for West Nile virus. Emerging Infectious Diseases 7:631-635.

Estrada-Franco, J. G., R. Navarro-Lopez, D. W. C. Beasley, L. Coffey, A.-S. Carrara, A. [P. A.] T. Da Rosa, T. Clements, E. Wang, G. V. Ludwig, A. C. Cortes, and others. 2003. West Nile virus in Mexico: Evidence of widespread circulation since July 2002. Emerging Infectious Diseases 9:1604-1607.

Ezenwa, V. O., M. S. Godsey, R. J. King, And S. C. Guptill. 2006. Avian diversity and West Nile virus: Testing associations between biodiversity and infectious disease risk. Proceedings of the Royal Society of London, Series B 273:109-117.

FanG, Y., And W. K. Reisen. 2006. Previous infection with West Nile or St. Louis encephalitis viruses provides cross protection during reinfection in House Finches. American Journal of Tropical Medicine and Hygiene 75:480-485.

Farfán-Ale, J. A., B. J. Blitvich, N. L. Marlenee, M. A. Loroño-Pino, F. Puerto-Manzano, J. E. García-Rejón, E. P. Rosado-Paredes, L. F. Flores-Flores, A. Ortega-Salazar, J. Chávez-Medina, ANd Others. 2006. Antibodies to West Nile virus in asymptomatic mammals, birds, and reptiles in the Yucatan Peninsula of Mexico. American Journal of Tropical Medicine and Hygiene 74:908-914.

Fonseca, D. M., N. Keyghobadi, C. A. Malcolm, C. Mehmet, F. Schaffner, M. Mogi, R. C. Fleischer, AND R. C. Wilkerson. 2004. Emerging vectors in the Culex pipiens complex. Science 303:1535-1538.

Gibbs, S. E. J., A. B. Allison, M. J. Yabsley, D. G. Mead, B. R. Wilcox, and D. E. Stallknecht. 2006. West Nile virus antibodies in avian species of Georgia, USA: 2000-2004. VectorBorne and Zoonotic Diseases 6:57-72.

Griffing, S. M., A. M. Kilpatrick, L. Clark, and P. P. Marra. 2007. Mosquito landing rates on nesting American Robins (Turdus migratorius). Vector-Borne and Zoonotic Diseases 7:437-443.

Guptill, S. C., K. G. Julian, G. L. Campbell, S. D. Price, and A. A. Marfin. 2003. Earlyseason avian deaths from West Nile virus as warnings of human infection. Emerging Infectious Diseases 9:483-484.

Hall, R. A., and A. A. Кнrомүкн. 2004. West Nile virus vaccines. Expert Opinion on Biological Therapy 4:1295-1305.

Hammon, W., W. Reeves, and M. Gray. 1943. Mosquito vectors and inapparent animal reservoirs of St. Louis and western equine encephalitis viruses. American Journal of Public Health 33:201-207.

Hassan, H. K., E. W. Cupp, G. E. Hill, C. R. Katholi, K. KLingler, and T. R. Unnasch. 2003. Avian host preference by vectors of eastern equine encephalomyelitis virus. American Journal of Tropical Medicine and Hygiene 69:641-647.

Hayes, C. 1989. West Nile fever. Pages 59-88 in The Arboviruses: Epidemiology and Ecology, vol. 5 (T. P. Monath, Ed.). CRC Press, Boca Raton, Florida.

Hayes, E. B., N. Komar, R. S. Nasci, S. P. Montgomery, D. R. O'Leary, and G. L. Campbell. 2005. Epidemiology and transmission dynamics of West Nile virus disease. Emerging Infectious Diseases 11: 1167-1173.

Health Canada. 2007. West Nile virus. [Online.] Available at www.phac-aspc.gc.ca/wnvvwn/index.htm.

Higgs, S., B. S. Schneider, D. L. Vanlandingham, K. A. Klingler, and E. A. Gould. 2005. Nonviremic transmission of West Nile 
virus. Proceedings of the National Academy of Sciences USA 102:8871-8874.

HochachKa, W. M., A. A. Dhondt, K. J. McGowan, and L. D. Kramer. 2004. Impact of West Nile virus on American Crows in the northeastern United States, and its relevance to existing monitoring programs. Ecohealth 1:60-68.

Hutcheson, H. J., C. H. Gorham, C. MachainWilliams, M. A. Lorono-Pino, A. M. James, N. L. Marlenee, B. Winn, B. J. Beaty, and C. D. Blair. 2005. Experimental transmission of West Nile virus (Flaviviridae: Flavivirus) by Carios capensis ticks from North America. Vector-Borne and Zoonotic Diseases 5:293-295.

KilPATRICK, A. M. 2006. Facilitating the evolution of resistance to avian malaria in Hawaiian birds. Biological Conservation 128:475-485.

Kilpatrick, A. M., A. A. Chmura, D. W. Gibbons, R. C. Fleischer, P. P. Marra, and P. Daszak. 2006a. Predicting the global spread of H5N1 avian influenza. Proceedings of the National Academy of Sciences USA 103:19368-19373.

Kilpatrick, A. M., P. DaszaK, S. J. Goodman, H. Rogg, L. D. Kramer, V. Cedeño, and A. A. Cunningham. 2006b. Predicting pathogen introduction: West Nile virus spread to Galápagos. Conservation Biology 20: 1224-1231.

Kilpatrick, A. M., P. Daszak, M. J. Jones, P. P. Marra, and L. D. Kramer. 2006c. Host heterogeneity dominates West Nile virus transmission. Proceedings of the Royal Society of London, Series B 273:2327-2333.

Kilpatrick, A. M., Y. Gluzberg, J. Burgett, and P. DAsZAK. 2004. Quantitative risk assessment of the pathways by which West Nile virus could reach Hawaii. Ecohealth 1:205-209.

Kilpatrick, A. M., L. D. Kramer, M. J. Jones, P. P. Marra, P. Daszak, and D. M. Fonseca. 2007. Genetic influences on mosquito feeding behavior and the emergence of zoonotic pathogens. American Journal of Tropical Medicine and Hygiene 77:667-671.

Kilpatrick, A. M., L. D. Kramer, S. R. Campbell, E. O. Alleyne, A. P. Dobson, and P. Daszak. 2005. West Nile virus risk assessment and the bridge vector paradigm. Emerging Infectious Diseases 11:425-429.

Kilpatrick, A. M., L. D. Kramer, M. J. Jones, P. P. Marra, and P. Daszak. 2006d. West Nile virus epidemics in North America are driven by shifts in mosquito feeding behavior. PLOS Biology 4:606-610.

Klenk, K., AND N. Komar. 2003. Poor replication of West Nile virus (New York 1999 strain) in three reptilian and one amphibian species. American Journal of Tropical Medicine and Hygiene 69:260-262.

Klenk, K., J. Snow, K. Morgan, R. Bowen, M. Stephens, F. Foster, P. Gordy, S. Beckett, N. Komar, D. Gubler, and M. Bunning. 2004. Alligators as West Nile virus amplifiers. Emerging Infectious Diseases 10:2150-2155.

Komar, N. 2003. West Nile virus: Epidemiology and ecology in North America. Advances in Virus Research 61:185-234.

Komar, N., and G. G. Clark. 2006. West Nile virus activity in Latin America and the Caribbean. Revista Panamericana De Salud Publica/Pan American Journal of Public Health 19:112-117.

Komar, N., S. Langevin, S. Hinten, N. Nemeth, E. Edwards, D. Hettler, B. Davis, R. Bowen, AND M. Bunning. 2003. Experimental infection of North American birds with the New York 1999 strain of West Nile virus. Emerging Infectious Diseases 9:311-322.

Komar, N., N. A. Panella, and E. Boyce. 2001. Exposure of domestic mammals to West Nile virus during an outbreak of human encephalitis, New York City, 1999. Emerging Infectious Diseases 7:736-738.

Komar, N., N. A. Panella, S. A. Langevin, A. C. Brault, M. Amador, E. Edwards, and J. C. Owen. 2005. Avian hosts for West Nile virus in St. Tammany Parrish, Louisiana, 2002. American Journal of Tropical Medicine and Hygiene 73:1031-1037.

Kramer, L. D., J. Li, and P.-Y. Shi. 2007. West Nile virus. Lancet Neurology 6:171-181.

LaDeau, S. L., A. M. Kilpatrick, and P. P. Marra. 2007. West Nile virus emergence and large-scale declines of North American bird populations. Nature 447:710-713.

Lanciotti, R. S., J. T. Roehrig, V. Deubel, J. Smith, M. Parker, K. Steele, B. Crise, K. E. Volpe, M. B. Crabtree, J. H. Scherret, and OTHERs. 1999. Origin of the West Nile virus responsible for an outbreak of encephalitis in the northeastern United States. Science 286:2333-2337.

Langevin, S. A., A. C. Brault, N. A. Panella, R. A. Bowen, AND N. Komar. 2005. Variation in virulence of West Nile virus strains 
for House Sparrows (Passer domesticus). American Journal of Tropical Medicine and Hygiene 72:99-102.

Lawrie, C. H., N. Y. Uzcátegui, E. A. Gould, And P. A. NutTall. 2004. Ixodid and argasid tick species and West Nile virus. Emerging Infectious Diseases 10:653-657.

Mahmood, F., R. E. Chiles, Y. Fang, C. M. BARKer, AND W. K. Reisen. 2004. Role of nestling Mourning Doves and House Finches as amplifying hosts of St. Louis encephalitis virus. Journal of Medical Entomology 41: 965-972.

Marra, P. P., S. Griffing, C. Caffrey, A. M. Kilpatrick, R. Mclean, C. Brand, E. Saito, A. P. Dupuis, L. [D.] Kramer, and R. NovaK. 2004. West Nile virus and wildlife. BioScience 54:393-402.

Mattar, S., E. Edwards, J. Laguado, M. González, J. Alvarez, and N. Komar. 2005. West Nile virus antibodies in Colombian horses. Emerging Infectious Diseases 11:1497-1498.

Molaei, G., T. G. Andreadis, P. M. Armstrong, J. F. Anderson, And C. Vossbrinck. 2006. Host feeding patterns of Culex mosquitoes and West Nile virus transmission, northeastern United States. Emerging Infectious Diseases 12:468-474.

Molaei, G., T. G. Andreadis, P. M. Armstrong, R. Bueno, JR., J. A. Dennett, S. V. Real, C. Sargent, A. Bala, Y. Randle, H. Guzman, and others. 2007. Host feeding pattern of Culex quinquefasciatus (Diptera: Culicidae) and its role in transmission of West Nile virus in Harris County, Texas. American Journal of Tropical Medicine and Hygiene 77:73-81.

Monath, T. P., ED. 1980. St. Louis Encephalitis. American Public Health Association, Washington, D.C.

Morales, M. A., M. Barrandeguy, C. Fabbri, J. B. Garcia, A. Vissani, K. Trono, G. Gutierrez, S. Pigretti, H. Menchaca, N. Garrido, AND OTHERs. 2006. West Nile virus isolation from equines in Argentina, 2006. Emerging Infectious Diseases 12:1559-1561.

Moudy, R. M., M. A. Meola, L. L. Morin, G. D. Ebel, and L. D. Kramer. 2007. A newly emergent genotype of West Nile virus is transmitted earlier and more efficiently by Culex mosquitoes. American Journal of Tropical Medicine and Hygiene 77:365-370.
Nasci, R. S., H. M. Savage, D. J. White, J. R. Miller, B. C. Cropp, M. S. Godsey, A. J. Kerst, P. Bennett, K. Gottfried, and R. S. Lanciotti. 2001. West Nile virus in overwintering Culex mosquitoes, New York City, 2000. Emerging Infectious Diseases 7: 742-744.

Nash, D., F. Mostashari, A. Fine, J. Miller, D. O'leary, K. Murray, A. Huang, A. Rosenberg, A. Greenberg, M. Sherman, AND OTHERs. 2001. The outbreak of West Nile virus infection in the New York City area in 1999. New England Journal of Medicine 344: 1807-1814.

Naugle, D. E., C. L. Aldridge, B. L. Walker, T. E. Cornish, B. J. Moynahan, M. J. Holloran, K. Brown, G. D. Johnson, E. T. Schmidtmann, R. T. Mayer, and others. 2004. West Nile virus: Pending crisis for Greater SageGrouse. Ecology Letters 7:704-713.

Nemeth, N., D. Gould, R. Bowen, AND N. Komar. 2006. Natural and experimental West Nile virus infection in five raptor species. Journal of Wildlife Diseases 42:1-13.

Ostfeld, R. S., And F. Keesing. 2000. Biodiversity and disease risk: The case of Lyme disease. Conservation Biology 14:722-728.

Owen, J., F. Moore, N. Panella, E. Edwards, R. Bru, M. Hughes, and N. Komar. 2006. Migrating birds as dispersal vehicles for West Nile virus. Ecohealth 3:79-85.

Petersen, L. R., AND E. B. Hayes. 2004. Westward ho?-The spread of West Nile virus. New England Journal of Medicine 351:2257-2259.

Peterson, A. T., D. A. Vieglais, and J. K. Andreasen. 2003. Migratory birds modeled as critical transport agents for West Nile Virus in North America. Vector-Borne and Zoonotic Diseases 3:27-37.

Platt, K. B., B. J. Tucker, P. G. Halbur, B. J. Blitvich, F. G. Fabiosa, K. Mullin, G. R. PARIKh, P. Kitikoon, L. C. Bartholomay, And W. A. Rowley. 2008. Fox squirrels (Sciurus niger) develop West Nile virus viremias sufficient for infecting select mosquito species. Vector-Borne and Zoonotic Diseases 8: in press.

Platt, K. B., B. J. Tucker, P. G. Halbur, S. Tiawsirisup, B. J. Blitvich, F. G. Fabiosa, L. C. Bartholomay, and W. A. Rowley. 2007. West Nile virus viremia in eastern chipmunks (Tamias striatus) sufficient for 
infecting different mosquitoes. Emerging Infectious Diseases 13:831-837.

Rappole, J. H., S. R. Derrickson, and Z. Hubálek. 2000. Migratory birds and spread of West Nile virus in the Western Hemisphere. Emerging Infectious Diseases 6:319-328.

Reeves, W. C. 1965. Ecology of mosquitoes in relation to arboviruses. Annual Review of Entomology 10:25-46.

Reisen, W. K., A. C. Brault, V. M. Martinez, Y. FanG, K. Simmons, S. Garcia, E. Omi-Olsen, AND R. S. LANE. 2007a. Ability of transstadially infected Ixodes pacificus (Acari: Ixodidae) to transmit West Nile virus to Song Sparrows or western fence lizards. Journal of Medical Entomology 44:320-327.

Reisen, W. K., Y. Fang, and V. Martinez. 2007b. Is nonviremic transmission of West Nile virus by Culex mosquitoes (Diptera: Culicidae) nonviremic? Journal of Medical Entomology 44:299-302.

Reisen, W. K., Y. Fang, and V. M. Martinez. 2005a. Avian host and mosquito (Diptera: Culicidae) vector competence determine the efficiency of West Nile and St. Louis encephalitis virus transmission. Journal of Medical Entomology 42:367-375.

Reisen, W. K., And D. C. Hahn. 2007. Comparison of immune responses of Brown-headed Cowbird and related blackbirds to West Nile and other mosquito-borne encephalitis viruses. Journal of Wildlife Diseases 43: 439-449.

Reisen, W. [K.], H. Lothrop, R. Chiles, M. Madon, C. Cossen, L. Woods, S. Husted, V. Kramer, and J. Edman. 2004. West Nile virus in California. Emerging Infectious Diseases 10:1369-1378.

Reisen, W. K., V. M. Martinez, Y. Fang, S. Garcia, S. Ashtari, S. S. Wheeler, and B. D. Carroll. 2006. Role of California (Callipepla californica) and Gambel's (Callipepla gambelii) quail in the ecology of mosquito-borne encephalitis viruses in California, USA. Vector-Borne and Zoonotic Diseases 6:248-260.

Reisen, W. K., S. S. Wheeler, S. Yamamoto, Y. FANG, AND S. Garcia. 2005b. Nesting ardeid colonies are not a focus of elevated West Nile virus activity in southern California. VectorBorne and Zoonotic Diseases 5:258-266.

Ringia, A. M., B. J. Blitvich, H.-Y. Koo, M. Van de Wyngaerde, J. D. Brawn, and R. J.
NovaK. 2004. Antibody prevalence of West Nile Virus in birds, Illinois, 2002. Emerging Infectious Diseases 10:1120-1124.

Root, J. J., P. T. Oesterle, N. M. Nemeth, K. Klenk, D. H. Gould, R. G. McLean, L. Clark, and J. S. Hall. 2006. Experimental infection of fox squirrels (Sciurus niger) with West Nile virus. American Journal of Tropical Medicine and Hygiene 75:697-701.

Sardelis, M. R., M. J. Turell, D. J. Dohm, And M. L. O'Guinn. 2001. Vector competence of selected North American Culex and Coquillettidia mosquitoes for West Nile virus. Emerging Infectious Diseases 7:1018-1022.

Savage, H. M., D. Aggarwal, C. S. Apperson, C. R. Katholi, E. Gordon, H. K. Hassan, M. Anderson, D. Charnetzky, L. McMillen, E. A. UnNAsch, AND OThers. 2007. Host choice and West Nile virus infection rates in blood fed mosquitoes, including members of the Culex pipiens complex, from Memphis and Shelby County, Tennessee 2002-2003. Vector-Borne and Zoonotic Diseases 7:365-386.

Scotr, T. W. 1988. Vertebrate host ecology. Pages 257-280 in Epidemiology of Arthropodborne Viral Diseases (T. P. Monath, Ed.). CRC Press, Boca Raton, Florida.

Styer, L. M., K. A. Bernard, and L. D. Kramer. 2006. Enhanced early West Nile virus infection in young chickens infected by mosquito bite: Effect of viral dose. American Journal of Tropical Medicine and Hygiene 75:337-345.

Tempelis, C. H. 1974. Host-feeding patterns of mosquitoes with a review of advances in analysis of blood meals by serology. Journal of Medical Entomology 11:635-653.

Tempelis, C. H., D. B. Francy, R. O. Hayes, AND M. F. Lofy. 1967. Variations in feeding patterns of seven culicine mosquitoes on vertebrate hosts in Weld and Larimer counties, Colorado. American Journal of Tropical Medicine and Hygiene 16:111-119.

Tempelis, C. H., W. C. Reeves, R. E. Bellamy, AND M. F. Lofy. 1965. A three-year study of feeding habits of Culex tarsalis in Kern County California. American Journal of Tropical Medicine and Hygiene 14:170-177.

Tesh, R. B., A. P. A. T. da Rosa, H. Guzman, T. P. Araujo, and S.-Y. XiaO. 2002. Immunization with heterologous flaviviruses protective against fatal West Nile encephalitis. Emerging Infectious Diseases 8:245-251. 
Theophilides, C. N., S. C. Ahearn, S. Grady, AND M. Merlino. 2003. Identifying West Nile virus risk areas: The dynamic continuous-area space-time system. American Journal of Epidemiology 157:843-854.

Tiawsirisur, S., K. B. Platt, R. B. Evans, and W. A. Rowley. 2005a. A comparision of West Nile virus transmission by Ochlerotatus trivittatus (COQ.), Culex pipiens (L.), and Aedes albopictus (Skuse). Vector-Borne and Zoonotic Diseases 5:40-47.

Tiansirisup, S., K. B. Platt, B. J. Tucker, and W. A. Rowley. 2005b. Eastern cottontail rabbits (Sylvilagus floridanus) develop West Nile virus viremias sufficient for infecting select mosquito species. Vector-Borne and Zoonotic Diseases 5:342-350.

Turell, M. J., D. J. Dohm, M. R. Sardelis, M. L. O'Guinn, T. G. Andreadis, and J. A. Blow. 2005. An update on the potential of North American mosquitoes (Diptera: Culicidae) to transmit West Nile virus. Journal of Medical Entomology 42:57-62.

Turell, M. J., M. [L.] O'Guinn, and J. Oliver. 2000. Potential for New York mosquitoes to transmit West Nile virus. American Journal of Tropical Medicine and Hygiene 62:413-414.

Turell, M. J., M. R. Sardelis, M. L. O'GuinN, AND D. J. Dohm. 2002. Potential vectors of West Nile virus in North America. Pages 241-252 in Japanese Encephalitis and West Nile Viruses (J. Mackenzie, A. Barrett, and V. Deubel, Eds.). Springer-Verlag, Berlin.

U.S. Geological Survey. 2007. West Nile virus maps. [Online.] U.S. Department of the Interior, U.S. Geological Survey, Washington, D.C. Available at diseasemaps.usgs.gov/.

Weaver, S. C., and A. D. T. Barrett. 2004. Transmission cycles, host range, evolution and emergence of arboviral disease. Nature Reviews Microbiology 2:789-801.

Yaremych, S. A., R. E. Warner, P. C. Mankin, J. D. Brawn, A. Raim, and R. NovaK. 2004. West Nile virus and high death rate in American Crows. Emerging Infectious Diseases 10:709-711.

Received 4 September 2007, accepted 29 September 2007 